\title{
How to understand real net ultrafiltration and its association with low blood pressure in critically ill patients with renal replacement therapy
}

\author{
Wei Li, Jinsong Zhang ${ }^{*}$ and Xufeng Chen
}

See related research by Murugan et al., https://ccforum.biomedcentral.com/articles/10.1186/s13054-018-2163-1.

\begin{abstract}
The concept of net ultrafiltration (UF ${ }^{\mathrm{NET}}$ ) mentioned in the paper by Murugan et al. in a recent issue of Critical Care does not equate to the real UF ${ }^{\mathrm{NET}}$ in patients with renal replacement therapy initiation. Furthermore, the baseline blood pressure among the groups had a statistically significant difference. Both of these two factors may affect the final results. Thus, we should be cautious interpreting the conclusions.
\end{abstract}

In a recent issue of Critical Care, Murugan and colleagues drew the conclusion that, among critically ill patients with $\geq 5 \%$ fluid overload, the patients with net ultrafiltration $\left(\mathrm{UF}^{\mathrm{NET}}\right.$ ) exceeding $25 \mathrm{ml} / \mathrm{kg} /$ day compared with those below $20 \mathrm{ml} / \mathrm{kg} /$ day had a lower 1-year risk-adjusted mortality [1]. The definition of $\mathrm{UF}^{\mathrm{NET}}$ in their paper was calculated as the difference between the volume of ultrafiltration and substitution fluids. Furthermore, for patients receiving continuous venovenous hemodiafiltration and slow continuous ultrafiltration, $\mathrm{UF}^{\mathrm{NET}}$ corresponded to the volume removed. However, for patients on renal replacement therapy, spontaneous urine output (UO) and intravenous fluid via the peripheral vein (Fiv) should also be taken into account for the estimation of total $\mathrm{UF}^{\mathrm{NET}}$. Thus, the total net ultrafiltration should be adjusted by $\mathrm{UF}^{\mathrm{NET}}+\mathrm{UO}-$ Fiv. We believe that this adjustment achieves a more accurate parameter to reflect the hemodynamic status of patients in clinical practice.

In addition, as shown in their study, the imbalance was observed for the mean arterial pressure among three different levels of $\mathrm{UF}^{\mathrm{NET}}$ intensity in all the patients receiving renal replacement therapy and the subset of patients receiving continuous renal replacement therapy $(P<0.001)$. It is well recognized that low blood pressure is a common complication during renal replacement therapy and is strongly associated with illness severity [2]. Low blood pressure will trigger an adjustment for total ultrafiltration volume. Thus, blood pressure appears to be a confounding factor to the results. Although adjusted by statistical models, it is better to re-analyze the association between $\mathrm{UF}^{\mathrm{NET}}$ intensity and mortality by categorized blood pressure levels to provide stronger evidence.

\footnotetext{
* Correspondence: Jiangsurm@126.com

Department of Emergency Medicine, The First Affiliated Hospital of Nanjing

Medical University, People's Hospital of Jiangsu Province, Nanjing 210029,

China
} 


\section{Authors' response}

\section{Raghavan Murugan, Rinaldo Bellomo, Paul M. Palevsky and John A. Kellum}

We would like to thank Dr. Li and colleagues for their thoughtful letter regarding our article [1]. They propose that we should account for urine output as well as the intravenous fluids administered in estimating the total $\mathrm{UF}^{\mathrm{NET}}$ volume. However, we would like to clarify that the purpose of our study was to examine whether there was an independent association between the process of care variable, $\mathrm{UF}^{\mathrm{NET}}$ intensity, and risk-adjusted 1-year mortality. Thus, we specifically did not include the urine output and the intravenous fluids in the calculation of $\mathrm{UF}^{\mathrm{NET}}$ (exposure variable) as it would confound the assessment of the relative contribution of $\mathrm{UF}^{\mathrm{NET}}$ intensity on the outcome.

In our study, all intravenous fluids administered, as well as fluid losses including the urine output, were part of the input and output equation to calculate the severity of fluid overload before initiation of renal replacement therapy as well as the cumulative fluid balance during renal replacement therapy (as outlined in Additional file 1: methods S2 [1]). The severity of fluid overload before initiation of renal replacement therapy as well as the cumulative fluid balance after initiation of renal replacement therapy were adjusted in all the multivariable regression models (Tables 3, 4, and 5 in [1]).

Nevertheless, we would like to acknowledge that in clinical practice there are variety of factors that are likely to influence the clinical decision to determine the target $\mathrm{UF}^{\mathrm{NET}}$ (e.g., starting fluid balance, ongoing fluid input/ output, patient tolerance of fluid removal, severity of illness and organ edema, etc.) and further research is required to determine the relative contribution of these variables on $\mathrm{UF}^{\mathrm{NET}}$ intensity and outcomes.

We completely agree with $\mathrm{Dr}$. Li and colleagues that even though we adjusted for mean arterial pressure as well as the vasopressor dose in the models, we cannot exclude the possibility of residual confounding by hemodynamics on $\mathrm{UF}^{\mathrm{NET}}$ intensity and outcomes. Although we could certainly perform a stratified analysis by mean arterial pressure, it would be difficult to fit models that account for continuous variation in blood pressure throughout the duration of renal replacement therapy and disentangle its association with $\mathrm{UF}^{\mathrm{NET}}$ intensity and the outcome.

\footnotetext{
Abbreviations output

Acknowledgements

None.

Funding

None.
}

Fiv: Fluid infusion by peripheral vein; UF ${ }^{\mathrm{NET}}$ : Net ultrafiltration; UO: Urine
Availability of data and materials

Not applicable.

Authors' contributions

WL drafted the letter. RM drafted the response. All authors have read, revised, and approved the final manuscript.

Ethics approval and consent to participate

Not applicable.

\section{Consent for publication}

Yes

Competing interests

The authors declare that they have no competing interests.

\section{Publisher's Note}

Springer Nature remains neutral with regard to jurisdictional claims in published maps and institutional affiliations.

Received: 1 November 2018 Accepted: 20 December 2018

Published online: 23 January 2019

\section{References}

1. Murugan R, Balakumar V, Kerti SJ, Priyanka P, Chang CH, Clermont G, Bellomo R, Palevsky PM, Kellum JA. Net ultrafiltration intensity and mortality in critically ill patients with fluid overload. Crit Care. 2018;22(1):223.

2. Bellomo R, Lipcsey M, Calavacca P, Haase M, Haase-Fielitz A, Licari E, Tee A, Cole L, Finfer S, Gallagher M, et al. Early acid-base and blood pressure effects of continuous renal replacement therapy intensity in patients with metabolic acidosis. Intensive Care Med. 2013;39(3):429-36.

Ready to submit your research? Choose BMC and benefit from:

- fast, convenient online submission

- thorough peer review by experienced researchers in your field

- rapid publication on acceptance

- support for research data, including large and complex data types

- gold Open Access which fosters wider collaboration and increased citations

- maximum visibility for your research: over 100M website views per year

At BMC, research is always in progress.

Learn more biomedcentral.com/submissions 